\title{
CUSTOMER BRAND RELATIONSHIP: PERAN BRAND LOVE TERHADAP BRAND COMMITMENT DAN POSITIVE WORD OF MOUTH
}

\author{
Catharina Clara \\ Dosen Program Studi Manajemen Fakultas Bisnis dan Akuntansi \\ Universitas Katolik Musi Charitas \\ e-mail : clara@ukmc.ac.id
}

\begin{abstract}
The purpose of this study is to find out how customer brand relationship, wheter strong consumer brand love influences willingness to spread positive word of mouth directly or through brand commitment. This research is a survey research, conducted in 5 cinema locations in Palembang. The analysis method uses mediated regression analysis. So the results of this study can explain whether brand love influences brand commitment and willingness to spread positive word of mouth.
\end{abstract}

\begin{abstract}
ABSTRAK
Tujuan dari penelitian ini adalah untuk mengetahui bagaimana hubungan merek pelanggan, apakah cinta merek konsumen yang kuat mempengaruhi kemauan untuk menyebarkan berita positif secara langsung atau melalui komitmen merek. Penelitian ini adalah penelitian survei, dilakukan di 5 lokasi bioskop di Palembang. Metode analisis menggunakan analisis regresi termediasi. Jadi hasil penelitian ini dapat menjelaskan apakah cinta merek memengaruhi komitmen dan kemauan merek untuk menyebarkan berita positif dari mulut ke mulut.
\end{abstract}

Kata Kunci : Hubungan Merek Pelanggan, Cinta Merek, Komitmen Merek, Word of Mouth Positif

\section{PENDAHULUAN}

Manusia dengan berbagai macam kebutuhan dan keinginan yang dinamis telah mewarnai dunia pemasaran sehingga begitu banyak produk barang maupun jasa yang diciptakan dan dikembangkan terus untuk memenuhi kebutuhan dan keinginan yang terus berubah pula. Mulai dari kebutuhan pokok atau primer seperti pangan, sandang, dan papan. Diikuti kebutuhan pelengkap seperti pendidikan, transportasi, dan hiburan. Konsumen dari segala lapisan kelas ekonomi mencari caranya sendiri-sendiri untuk memenuhi kebutuhannya tersebut sehingga pemasarpun harus jeli dalam menangkap target segmen pasar yang akan ditangkap untuk dilayani.

Dunia hiburan di tanah air diwarnai oleh beraneka jenis hiburan mulai dari yang ditujukan ke segmen tertentu seperti anak-anak sampai dengan orang dewasa, mulai dari kelas bawah sampai kelas menengah atas. Salah satu hiburan yang tergolong murah adalah menonton bioskop yang mulai berkembang kembali setelah mengalami keterpurukan era 1991-2002. Menonton bioskop dapat menjadi alternatif hiburan yang singkat dan menyenangkan serta cukup fleksibel dengan banyaknya tawaran pilihan dan jadwal pemutaran film. Fasilitas yang disediakan di bioskop jaringan dewasa ini juga semakin lengkap dan menarik sehingga dapat memenuhi kebutuhan sensasi menonton yang berbeda daripada menonton di rumah atau mengakses film secara gratis. Misalnya, sofa yang ekstra empuk dan nyaman, layar yang ekstra lebar, fasilitas speaker sound 
system yang luar biasa yang membuat menonton film seperti menyaksikan kejadian sebenarnya dengan suara yang dihasilkan lebih dramatis.

Berkembangnya gaya hidup hedonis dan peka sosmed dewasa ini juga membuat kegiatan menonton bioskop menjadi salah satu gaya hidup yang kembali ngetren dewasa ini. Melalui media sosial, konsumen dengan sukarela secara tidak sengaja ikut mempromosikan bioskop maupun film yang ditontonnya. Hal ini mendorong audiens media sosial yang tidak ingin ketinggalan film terbaru atau yang sedang mencari kegiatan mengisi waktu luangnya dapat menjadikan menonton sebagai salah satu alternatif. Kegiatan promosi yang dilakukan oleh konsumen ini secara tidak langsung membantu produsen dalam mempromosikan bioskopnya. Upaya konsumen inilah merupakan word of mouth yang diharapkan positif oleh para pengusaha bioskop. Contoh word of mouth positif misalnya postingan yang menampilkan foto tiket akan memperlihatkan nama film dan sekaligus letak atau nama bioskopnya. Sehingga pembicaraan antara nama film dan nama bioskop memang tidak dapat dipisahkan. Isi pembicaraan yang lebih metitikberatkan kepada kelebihan atau kekurangan bioskopnya daripada filmnya akan disoroti sebagai WOM positif bagi bioskop yang bersangkutan. Berkembangnya blog blog pribadi dengan tulisan-tulisan sesuai minatan termasuk bahasan mengenai dunia perbioskopan juga merupakan bentuk lain dari WOM positif ini.

Selain itu bioskop jaringan juga begitu aktif dan gencar menawarkan bermacammacam paket promosi, baik aneka promosi yang bekerja sama dengan perbankan seperti pembelian dengan kartu kredit atau plastic/ electronic money lainnya maupun promosi dalam upaya mempertahankan pelanggan dalam bentuk customer relationship marketing. Kegiatan mempertahankan pelanggan ini dirasa sangat penting mengingat persaingan yang semakin ketat di dunia bisnis bioskop.

Shimp dan Madden (1998) menunjukkan bahwa manusia dapat memiliki cinta terhadap benda bukan manusia, misalnya sebuah merek. Mereka menunjukkan bahwa cinta merek terdiri dari 3 dimensi yaitu: passion, intimacy, dan commitment. Penelitian belakangan ini (Batra, et.al., 2012; Albert, et.al., 2008) juga mulai menunjukkan bahwa konsumen memiliki perasaan cinta terhadap merek yang mereka pakai. Dari perkembangan bisnis bioskop di atas menunjukkan bahwa persaingan semakin ketat dalam merebut hati konsumen. Maka bagaimana bioskop dapat menyentuh sisi kecintaan akan merek ini sehingga konsumen merasakan hubungan yang lebih intim dengan bioskop langganannya dan berpengaruh kepada komitmen merek.

Seperti halnya manusia yang jatuh cinta lalu mencintai pasangannya dan akhirnya berkomitmen untuk hidup berdua dalam pernikahan, mereka pun cenderung untuk tidak menjelekkan pasangannya, karena dengan menjelekkan pasangannya menunjukkan kebodohan mereka sendiri dalam memilih pasangan. Komitmen merek yang dimiliki konsumen mengakibatkan kesukarelaan atau keinginan mereka untuk menyebarkan WOM positif merek favoritnya kepada orang lain. WOM merupakan salah satu dari cara-cara yang memiliki efek yang paling efektif terhadap orang dan mempengaruhi orang untuk membeli produk atau jasa lebih daripada iklan yang lain karena orang biasanya lebih mempercayai apa yang mereka dengar langsung dari orang lain daripada iklan yang membayar endorser-nya untuk bicara tentang produk ataupun tenaga penjualan yang memang dibebani target untuk menjual produk. Dengan komitmen yang dimilikinya, seorang konsumen bukan hanya mempertahankan hubungan jangka panjangnya dengan merek, melainkan juga ingin mengajak orang lain mengikutinya dengan menyebarkan WOM positif 
mengenai merek. Hal ini bertujuan semakin meyakinkan dirinya sendiri bahwa pilihannya sudah tepat. Penelitian ini oleh karena itu berusaha menjawab pertanyaan-pertanyaan berikut.

1. Bagaimana brand commitment memediasi hubungan antara brand love dengan Positive Word of Mouth $(P W O M)$ ?

2. Bagaimana pengaruh brand love terhadap brand commitment dan bagaimana pula pengaruh brand commitment terhadap PWOM?

3. Bagaimana brand love secara langsung mempengaruhi kerelaan menyebarkan PWOM ?

\section{Consumer Brand Relationship}

Konsep Consumer Brand Relationship (selanjutnya disingkat CBR) diperkenalkan pertama kali oleh Shimp dan Madden (1988). Mereka mendefinisikan CBR sebagai bentuk hubungan konsumen dengan objek konsumsi (misalnya produk, merek, toko, dll.), yang berkisar dari perasaan negatif seperti antipati atau benci, untuk sedikit suka, semua berjalan seperti biasa sampai ada muncul perasaan positif seperti hubungan antar personal, bahkan hingga adanya sejumlah rasa cinta (Shimp dan Madden, 1988). Pada artikel mengenai CBR yang paling banyak diterima, Fournier (1998) menyatakan bahwa merek mungkin menjadi sebuah partner hubungan yang aktif bagi konsumen dan memberikan makna dalam konteks psikososio-kultural. Kumar (2006) mendefinsikan hubungan dengan merek bukanlah apa-apa, namun hal ini untuk mengetahui bagaimana orang membuat komitmen jangka panjang terhadap objek nyata yang mereka beli dan gunakan, demikian juga dalam membantu membuat, menjual, dan mendistribusikan. Dari pandangan yang lebih komprehensif mengenai hubungan merek, Keller (2001) menyatakan hubungan mereka sebagai sebuah resonansi merek yang menggambarkan sifat dari hubungan dan tingkat di mana konsumen merasa mereka sehati dengan merek.

Dalam arena CBR, Fournier (1998) merupakan yang pertama mengidentifikasi domain kunci CBR. Studinya menunjukkan data dari 112 deskripsi konsumen mengenai brand relationship untuk menganalisis domain utama dalam CBR. Penelitian tersebut menemukan 7 dimensi CBR teoritis yaitu: 1. Sukarela lawan terpaksa; 2. Intensif lawan superficial; 3. Positif lawan negatif; 4. Jangka panjang lawan jangka pendek; 5. Formal lawan informal; 6. Publik lawan privat; 7. Simetrik lawan asimetrik. Setelah itu studi mengenai CBR terus berkembang. Degon (2000) mengusulkan 3 dimensi CBR, yaitu: 1. Hubungan asistensi; 2. Hubungan pedagogik; 3. Hubungan otoritas. Penjelasan ketiga jenis hubungan tersebut adalah, untuk hubungan kategori pertama, merek mencari cara membantu konsumen. Untuk kategori kedua, merek menyesuaikan perilakunya untuk merespon kebutuhan konsumen. Pada kategori hubungan otoritas, merek mentransfer otoritasnya atau mendorong kepribadiannya kepada hubungan dengan konsumen. Dalam penelitian Fritz dan Lorenz (2010) membentuk 9 dimensi berdasar pendekatan pada psikologi sosial terhadap hubungan interpersonal. Berdasar teori tersebut mereka mengusulkan 9 dimensi CBR yaitu: 1. Interdependensi; 2. Durasi hubungan; 3. Kepuasan; 4. Komitmen Merek; 5. Perilaku aktual; 6. Ekuitas; 7. Rasa percaya terhadap merek; 8. Passion; 9. Keintiman.

\section{Brand Love}

Kecintaan terhadap merek diinspirasi dari bentuk-bentuk cinta antar manusia di segala kelompok manusia di sepanjang sejarah hidup manusia (Hutfield dan Rapson, 1993). Untuk menjalin sebuah hubungan yang sukses, cinta adalah sebuah komponen penting (Simpson, et.al., 2001). Para peneliti merek mulai meyakini ada kesamaan hubungan antara konsumen dan merek dan menandakan karakteristik 
yang sama dengan hubungan antar personal (Aaker, 1997; Fournier, 1998). Shimp dan Madden (1998) menunjukkan bahwa manusia dapat memiliki cinta terhadap benda bukan manusia, misalnya sebuah merek. Mereka menunjukkan bahwa cinta merek terdiri dari 3 dimensi yaitu: passion, intimacy, dan commitment. Penelitian belakangan ini (Batra, et.al., 2012; Albert, et.al., 2008) juga mulai menunjukkan bahwa konsumen memiliki perasaan cinta terhadap merek yang mereka pakai.

Kecintaan terhadap merek adalah derajat ketertarikan dan ketergantungan yang diinginkan pelanggan terhadap sebuah nama merek khusus (Caroll \& Ahuvia, 2006). Mungkin ada yang membandingkan dengan menyukai merek. Namun kecintaan terhadap merek berbeda dengan menyukai merek karena mencintai merek terintegrasi dengan diri konsumen itu sendiri dan memiliki hubungan jangka panjang terhadap merek. Sehingga cinta mereka lebih mendalam dan jangka panjang daripada menyukai merek. Luaran utama dari cinta merek adalah positive word of mouth, brand loyalty, selfexpressive, dan hedonistic brand. Besarnya kecintaan terhadap merek bergantung pada 2 aspek minat terhadap sebuah merek yaitu brand affection dan brand passion.

\section{Brand affection}

Afeksi merek didefinisikan sebagai sebuah keintiman (Hortfield, 1988), atau ketergantungan (Fisher, 2006). Ketergantungan adalah sebuah elemen yang menunjukkan minat atau keintiman. Sebagai contoh (Sternber, 1977) mendefinisikan keintiman sebagai: sebuah perasaan kedekatan, kasih sayang dan kesetiaan dalam isu cinta. Albert, et.al. 2008 menyajikan ukuran afeksi merek yang mengandung elemen sekunder dari kecintaan merek dalam hubungan 5 elemen utama berikut: brand intimacy, dream about brand, term of relationship, brand memories, dan brand uniqueness. a. Keintiman merek menurut Sternberg (1977) pada Bauer \& Heinrich (2006) adalah kedekatan, keakraban dan kasih sayang dalam hubungan di antara manusia.

b. Memimpikan merek adalah curahan hati pelanggan atau pelanggan menunjukkan mimpi mereka mengenai merek, di mana menunjukkan kehadiran merek di pikiran mereka. Dalam hubungan interpersonal, ada hubungan antara cinta dan memikirkan tentang pasangan. Lamanya waktu memikirkan tentang pasangan merupakan tanda yang baik untuk cinta di masa depan.

c. Sifat hubungan, lamanya hubungan dengan sebuah merek bergantung pada keintiman yang mengacu pada kedalaman keakraban terhadap pasangan, sebagai hasil tinggal bersama dalam jangka waktu lama. Umur hubungan yang lama ini menunjukkan tingkat kepuasan.

d. Kenangan merek, sebuah merek dapat menimbulkan kenangan positif dan penting bagi konsumen atau dapat berupa sebuah perasaan nostalgia (baik mengenai sejarah, masa kecil, pengalaman pertama). Hal ini merupakan elemen khusus dari cinta non human, karena tidak ada tanda dalam teori cinta antar pribadi.

e. Keunikan merek: hasil yang didapatkan dari pengumpulan opini menunjukkan bahwa merek telah dipilih secara berbeda atau unik. Hal ini mungkin berhubungan dengan perasaan ideal.

\section{Brand Passion}

Kegemaran terhadap merek adalah struktur psikologis pada dasar penyelidikan antar personal, dan didefinisikan sebagai keisengan merek, antusiasme merek, tergila-gila, atau bahkan sebuah kebencian yang tak berdasar terhadap sebuah merek (Albert \& Merunka, 2013). Dalam penilaian 
kecintaan terhadap merek, Albert \& Merunka, (2013) menghubungkan faktor sekunder kegemaran terhadap merek ini ke dalam 2 faktor dasar yang terdiri dari brand pleasure dan brand idealization.

a. Brand pleasure (kesenangan akan merek). Dalam brand love, kesenangan merupakan efek positif dari lamanya hubungan.

b. Brand idealization (mengidamkan merek). Idealisasi artinya mengidealkan, perfeksionis ideal dan memamerkan. Jadi konsumen dapat membayangkan sebuah merek sebagai harapan tertinggi mereka, sehingga mereka dapat mempercayai merek karena telah menempati posisi yang sempurna dalam benak mereka.

\section{Brand Commitment}

Komitmen merek adalah pernyataan psikologis yang menunjukkan sikap positif konsumen terhadap sebuah merek dan keinginan untuk menjalin hubungan dengan sebuah produk barang maupun jasa. (Albert \& Merunka, 2013). Konsumen dengan komitmen yang tinggi mengembangkan hubungan yang kuat dengan merek demikian pula dengan kecenderungan untuk menjalin hubungan semacam itu (Walsh, et.al., 2010). Komitmen adalah sebuah faktor mutidimensional, namun dalam beberapa penelitian disebut sebagai satu dimensional. Allen dan Meyer (1990) telah menyebutkan karakteristik komitmen sebagai sebuah afektif dan kotinuans. Komitmen afektif didasarkan pada keterikatan emosional atau afektif terhadap organisasi sehingga individu merasa terikat secara kuat untuk mengidentifikasi dirinya terhadap merek, terlibat dengan merek, dan menikmati keanggotaan dalam organisasi. Komitmen kontinuans adalah hubungan pertukaran yang dibangun pada sisi yang bersifat ekonomis, biaya perpindahan merek, dan keterbatasan dari alternatif (Ziaullah, et. al., 2015). Komitmen merek dapat bersifat ekonomis, emosional, dan psikologis antar konsumen dengan merek. Dalam faktanya komitmen terbagi atas 2 bagian. Komitmen dalam basis biaya berarti sesorang tetap dalam hubungan karena tidak ada lagi pilihan yang dapat diperbandingkan atau biaya untuk berpindah kepada pilihan lain terlalu tinggi, yang dinamakan komitmen kontinuans (Albert \& Merunka, 2013). Komitmen afektif berbeda dengan komitmen kontinuans. Komitmen afektif adalah semacam afeksi emosional terhadap sebuah nama komersial atau organisasi dalam basis mengidentifikasi sebuah merek atau perusahaan. Komitmen afektif adalah kecenderungan untuk mempertahankan hubungan dengan merek dalam basis identifikasi nilai. Konsumen ini cenderung memiliki kecenderungan untuk membayar lebih dan mereka menggunakan nama merek komersial dalam segala situasi (Tory, et.al., 2013).

\section{Positive Word of Mouth}

Berita dari mulut ke mulut (selanjutnya disingkat menjadi $W O M$ ) adalah berbicara mengenai produk dan jasa di antara orangorang di luar periklanan produk dan jasa yang dilakukan perusahaan. Pembicaraan ini dapat menjadi percakapan yang saling menguntungkan atau bisa berupa nasehat dan saran-saran. Namun, poin utama dari pembicaraan ini adalah dilakukan oleh orang-orang yang mendapatkan keuntungan yang sangat rendah dalam mempersuasi orang lain untuk menggunakan produk. WOM lebih daripada membicarakan tentang produk. WOM merupakan salah satu dari cara-cara yang memiliki efek yang paling efektif terhadap orang dan mempengaruhi orang untuk membeli produk atau jasa lebih daripada iklan yang lain karena orang biasanya lebih mempercayai apa yang mereka dengar langsung dari orang lain daripada iklan yang membayar endorsernya untuk bicara tentang produk ataupun tenaga penjualan yang memang dibebani target untuk menjual produk.

Ike-Elechi \& Tan (2009) meneliti tentang efek brand image pada brand 
faithfulness dan brand commitment di China. Analisis perilaku menunjukkan bahwa brand image memiliki dampak positif dan berarti terhadap minat pelanggan dan komitmen terhadap merek, dan citra favorit ini memiliki efek jangka panjang pada citra yang ada dalam pikiran pelanggan mengenai kualitas merek dan menghasilkan kepuasan dan komitmen terhadap merek.

Tuskej, et.al., (2013) meneliti hubungan di antara congruity of brandconsumer's value, consumer's identity, consumer commitment dan word of mouth. Hasil menunjukkan bahwa kecocokan nilai antara konsumen dengan merek berdampak positif terhadap brand commitment. Identitas konsumen meningkatkan komitmen terhadap merk dan WOM mengenai merek. Komitmen konsumen terhadap merek berdampak positif dan meningkatkan WOM mengenai merek.

Unal \& Aydin (2013) meneliti faktorfaktor yang mempengaruhi brand love. Hasil penelitian menunjukkan bahwa brand interest memiliki pengaruh yang positif dan berarti pada brand faithfulness dan pemasaran WOM. Juga brand image dan self-sociality berdampak positif terhadap brand love namun variasinya tidak memiliki pengaruh yang bermakna pada brand interest; Dalam faktanya, brand image berpengaruh negatif pada brand faithfulness.

Albert \& Merunka (2013) meneliti efek brand love pada hubungan konsumen dengan merek. Hasil penelitian menunjukkan hubungan yang kuat antara 2 faktor sebelumnya yaitu (brand identity dan brand trust) dengan brand love dan 3 faktor setelahnya yaitu (word of mouth, membayar harga lebih tinggi, brand commitment) dengan brand love. Juga dikonfirmasi efek komitmen yang berarti pada word of mouth.

Motahari et.al., (2014) meneliti hubungan antara merek dan konsumen. Hasil menunjukkan bahwa brand experience berdampak positif dan berarti pada brand satisfaction, brand trust, brand commitment, dan brand love. Brand satisfaction dan brand trust berdampak positif dan berarti terhadap brand love dan brand commitment. Brand love dan brand commitment berdampak positif dan berarti pada WOM dan brand faithfulness.

Bachman \& Wilkins (2014) meneliti brand commitment dan identifikasi konsumen terhadap merek sebagai faithfulness dan minat membeli. Tujuan penelitian ini adalah menilai dampak dari faktor-faktor ini terhadap minat membeli dan WOM mengenai merek. Hasil menunjukkan bahwa kecocokan dengan merek tidak memiliki efek langsung terhadap komitmen. Identifikasi pelanggan terhadap merek berdampak pada komitmen afektif namun tidak memilik efek lanjutan kepada komitmen. Namun, komitmen memiliki arti dan pengaruh berkelanjutan terhadap WOM. Komitmen afektif tidak berdampak pada minat membeli, namun komitmen berkelanjutan memiliki dampak yang berarti dan positif terhadap minat membeli.

Rizwan, M., et.al. (2014) meneliti tentang kontribusi brand equity, perceived quality, consumer satisfaction, brand commitment, brand credibility dan brand trust untuk membangun brand loyalty. Penelitian ini menjelaskan bagaimana pelanggan menjadi setia kepada merek di mana kebutuhan mereka sekarang dan di masa depan sudah dipenuhi oleh merek. Hasil penelitian ini menunjukkan bahwa semua variabel menunjukkan dampak positif dan signifikan terhadap brand loyalty.

Sallam, M.A. (2015), citra positif mengenai perusahaan maupun merek berperan penting dalam merangsang pelanggan untuk membeli produk dan jasa perusahaan. Ketika pelanggan memiliki kesan positif mengenai citra perusahaan dan juga merek perusahaan, maka mereka berfokus pada aspek perusahaan dan seiring berjalannya waktu, pelanggan memiliki kesetiaan terhadap perusahaan dan mereknya. Lebih jauh lagi, mereka 
biasanya menunjukkannya dengan menggunakan WOM positif, yang pada akhirnya merupakan tujuan dari setiap perusahaan. Sehingga alasan perusahaan memanfaatkan citra perusahaan dan merek ini adalah mereka, baik secara langsung maupun tidak langsung memiliki dampak kuat yang membangun loyalitas pelanggan dan membuat mereka berbicara lebih positif tentang perusahaan. Hasil penelitian menunjukkan bahwa citra merek memiliki pengaruh positif yang lebih terhadap kesetiaan pelanggan daripada citra perusahaan. Kesetiaan pelanggan berdampak positif terhadap WOM positif dari pelanggan.

Wien, A.H. (2015), hasil penelitian ini memberikan temuan berharga bagi praktisi pemasaran. Pertama, perusahaan yang hendak merangsang WOM positif seharusnya mendapatkan evaluasi positif dari kualitas dan kepuasan. Walaupun kedua indikator WOM ini bervariasi dalam kekuatan tergantung dari konteks, pemasar seharusnya berhati-hati ketika mengumpulkan umpan balik konsumen untuk memprediksi terjadinya WOM positif. Kedua, hasil penelitian ini memberikan pengetahuan bahwa peningkatan diri sebagai motivasi pusat WOM dapat membantu usaha perusahaan dalam merangsang WOM. Sebagai contoh, pemasar dapat menggunakan pesan iklan yang menarik untuk pengembangan konsep diri dari para pemirsa, misalnya, “ Merek ini membuat Anda keluar dari kekacauan", atau Produk ini menunjukkan bahwa Anda adalah seorang ahli seni". Ketiga, disertasi ini memberikan pandangan kepada perusahaan berkenaan dengan mentargetkan pelanggan untuk kampanye WOM mereka. Ditunjukkkan bahwa kepribadian tertentu memainkan peranan penting dalam melakukan WOM. Sebagai contoh, dengan mengidentifikasi pelanggan yang merupakan seorang ekstrovert dan memiliki kepercayaan diri sosial yang tinggi (misalnya, melalui kuesioner online singkat), perusahaan mungkin dapat membangun kontak dengan bibit yang menarik untuk persemaian kampanye WOM mereka. Keempat, penelitian ini menunjukkan bahwa pelanggan sering membela perusahaan dan merek melawan WOM negatif pada media online. Sehingga ketika perusahaan sibuk mencari cara menangani WOM negatif, disertasi ini menyarankan bahwa perusahaan seharusnya tetap kalem ketika diskusi WOM negatif meningkat dan menahan diri mereka untuk masuk dalam diskusi terlalu cepat. Pelanggan sering membela mereka.

Hassan, M., et.al. (2016), penelitian ini mengidentifikasi dampak variabel yang cenderung membuat pelanggan menjadi advocate. Dewasa ini perusahaan harus memfokuskan diri pada pelanggan lebih sering dan lebih konsisten daripada berfokus pada periklanan dan promosi karena pasar yang kompetitif. Penelitian ini membantu merek memfokuskan pada apa yang diinginkan konsumen dan mengapa menciptakan advocate ini perlu. Hasil penelitian menunjukkan bahwa variabel seperti customer service, trust in brand dibangun melalui kualitas produk, brand salience, secara signifikan memengaruhi dalam mengubah pelanggan menjadi advocates. Namun komitmen merek tidak selalu penting, mengingat pelanggan lebih sering mencari variasi dan memiliki keinginan mencoba produk baru dan merek baru. Hasil menunjukkan bahwa brand love memoderasi hubungan di antara differentiated customer service (DCS), BS, and brand advocacy (BA), namun ada dampak moderasi yang tidak signifikan ditemukan antara brand commitment and $B A$.

Sweiden, K.M. (2016), penelitian ini menyelidiki dampak dari social influence, Brand Image and Brand Love terhadap Word of Mouth pada perusahaan telekomunikasi di Amman. Untuk mencapai tujuan penelitian, digunakan metode analisis deskriptif dan analisis regresi berganda serta analisis jalur untuk menguji 8 hipotesis penelitian yang didasarkan dari pertanyaan penelitian dan 
untuk menemukan pengaruh langsung maupun tak langsung di antara variabel bebas, variabel terikat, dan variabel mediator. Variabel bebasnya adalah Social Influence, variabel terikatnya adalah Word of Mouth, dan variabel mediatornya adalah Brand Image dan Brand Love. Penelitian ini menemukan sejumlah hasil yaitu: ada efek positif signifikan social influence pada brand image, brand love dan WOM; ada efek positif signifikan brand image pada brand love and WOM; ada efek positif signifikan brand love pada word of mouth; ada efek positif signifikan dari brand image sebagai mediator pada hubungan antara social influence and word of mouth; ada efek positif signifikan brand love sebagai mediator pada hubungan antara social influence dan word of mouth.

Gupta, Richa (2017), menguji brand re -purchase intention di antara konsumen sebagai hasil dari faktor-faktor kelembaman. Reaksi konsumen terhadap faktor-faktor kelembaman seperti perasaan cinta terhadap merek dipelajari untuk menganalisis perilaku pembelian ulang mereka. Hasil menunjukkan bahwa faktor kelembaman secara signifikan mempengaruhi minat membeli ulang merek. Lebih jauh, brand love mengakibatkan hasil yang berbeda dalam mempengaruhi minat beli ulang pada konsumen $F M C G$.

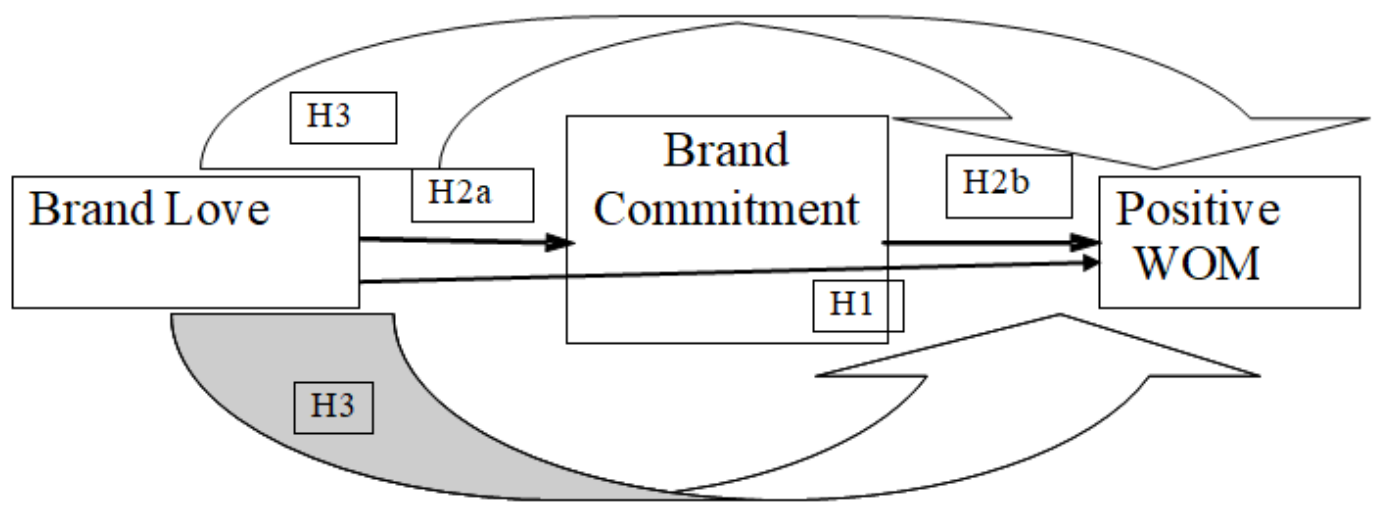

Diadaptasi dari berbagai sumber (Aaker, 1997; Fournier, 1998; Shimp dan Madden, 1998; Batra, et.al., 2012; Albert, et.al., 2008; Caroll \& Ahuvia, 2006; Albert \& Merunka, 2013) dan dikembangkan sendiri

\section{Gambar 1. Kerangka Teoritis}

\section{Pengembangan Hipotesis}

Berdasarkan uraian di atas maka akan diuji hubungan antara variabel sebagai berikut:

H1: Brand Love berpengaruh positif terhadap Positive WOM melalui Brand Commitment sebagai variabel mediasi

H2a: Brand Love berpengaruh positif terhadap Brand Commitment

$\mathrm{H} 2 \mathrm{~b}$ : Brand Commitment berpengaruh positif terhadap Positive WOM
H3: Brand Love secara langsung berpengaruh positif terhadap Positive WOM

Menganalisis dan mencari bukti empiris mengenai bagaimana brand love mempengaruhi brand commitment dan kerelaan dalam menyebarkan WOM positif? Sehingga hasil penelitian ini dapat dimanfaatkan untuk penelitian selanjutnya dan untuk praktisi pemasaran dalam mengembangkan strategi pemasarannya khususnya dalam bentuk customer brand relationship. 


\section{METODE}

Penelitian ini merupakan penelitian survey, yang dilakukan di 5 lokasi yang dipilih yaitu di 5 bioskop di Palembang antara lain Cinemaxx PIcon, Cinema XXI PIM dan PS, Cinema 21 OPImal, dan CGV Veteran. Satuan sampel sekunder yaitu pelanggan bioskop akan dipilih dari setiap bioskop. Pelanggan yang dipilih adalah pelanggan yang telah dewasa (berumur minimal 17 tahun) dan sudah menjadi pelanggan minimal selama 6 bulan (bila ada kartu keanggotaan) atau menonton di tempat yang sama minimal $3 x$ selama 6 bulan terakhir. Calon responden yang memenuhi syarat (setelah dilakukan tanya jawab singkat) diminta kesediaannya mengisi kuesioner pada waktu menunggu pemutaran film dengan pertimbangan pelanggan dalam keadaan santai. Apabila setelah selesai menonton kemungkinan besar mereka tergesa-gesa untuk meninggalkan tempat. Teknik pengumpulan data yang digunakan adalah survei tatap muka kepada pelanggan yang terpilih pada bioskop yang terpilih. Dengan survei secara langsung maka dapat diberikan penjelasan kuesioner apabila diperlukan penjelasan oleh responden. Waktu penyebaran kuesioner selama kurang lebih 2 bulan. Setelah dilakukan penyebaran kuesioner, terkumpul 160 lembar kuesioner namun setelah data direkapitulasi, diperiksa kelengkapan dan konsistensi jawaban, maka didapatkan 153 lembar kuesioner yang dapat diolah lebih lanjut.

Dalam penelitian diselidiki apakah betul bahwa cinta yang semakin mendalam bisa mewujudkan sebuah komitmen. Mengingat dasar teori customer brand relationship ini adalah hubungan interpersonal manusia. Apakah hubungan pelanggan dengan merek yang dicintainya bisa meningkat menjadi komitmen terhadap merek dan bahkan menjadi motivasi untuk ikut mempromosikan mereknya dengan sukarela dengan menyebarkan WOM positif kepada konsumen lainnya.

\section{Operasionalisasi Variabel}

Ketiga variabel penelitian ini adalah 1. Brand Love (variabel bebas), 2. Brand Commitment (variabel mediator), 3. Positive Word of Mouth (variabel terikat. Ketiga variabel diukur dengan 5 skala Likert, berkisar dari Sangat Setuju s.d. Sangat Tidak Setuju. Operasionalisasi dari ketiga variabel penelitian ini dirinci pada Tabel 1 berikut.

Tabel 1. Operasionalisasi Variabel

\begin{tabular}{|c|c|c|c|}
\hline No. & Variabel & Indikator & Butir Pernyataan (Skala Likert) \\
\hline 1. & $\begin{array}{l}\text { Brand Love } \\
\text { (Albert, et.al., 2008; Maisam } \\
\text { dan Mahsa, 2016) }\end{array}$ & $\begin{array}{l}\text { Brand Passion } \\
\text { *Pleasure } \\
\text { *Idealization } \\
\text { Brand Affection } \\
\text { - Uniqueness } \\
\text { - Dream } \\
\text { - Duration } \\
\text { - Intimacy } \\
\text { - Memories }\end{array}$ & $\begin{array}{l}\text { BP1 Saya mendapatkan kesenangan ketika menonton di } \\
\text { sini. } \\
\text { BP2 Tidak ada tempat nonton lain yang menyenangkan } \\
\text { seperti di sini. } \\
\text { BA1u Merek bioskop ini spesial bagi saya. } \\
\text { BA2u Bioskop ini unik, lain daripada bioskop lain. } \\
\text { BA3dr Bila hendak menonton film terbaru, bioskop inilah } \\
\text { yang saya pilih. } \\
\text { BA4du Sudah lama saya menjadi langganan bioskop ini. } \\
\text { BA5i Saya merasa adanya hubungan yang hangat dan } \\
\text { nyaman dengan bioskop ini. }\end{array}$ \\
\hline
\end{tabular}




\section{Brand Commitment \\ (Tuskej, et.al., 2013; Papista \& Dimitri-adis, 2012; Zhou, et.al., 2013) \\ 3. Positive Word of Mouth (Tuskej, et.al, 2013; Kunzel dan Halliday, 2008, Sichtmann, 2007)}

Merupakan pernyataan
psikologis yang
menunjukkan sikap positif
konsumen terhadap sebuah
nama merek dan keinginan
untuk menjalin hubungan
jangka panjang dengan
produk atau jasa.
Berita dari mulut ke mulut
(WOM) adalah berbicara
mengenai produk dan jasa di
antara orang-orang di luar
periklanan produk dan jasa
yang dilakukan perusahaan.
Pembicaraan ini dapat
menjadi percakapan yang
saling menguntungkan atau
bisa berupa nasehat dan
saran-saran. Namun, poin
utama dari pembicaraan ini
adalah dilakukan oleh orang-
orang yang mendapatkan
keuntungan yang sangat
rendah dalam mempersuasi
orang lain untuk
menggunakan produk.

BA6i Saya merasa dekat secara emosional dengan merek bioskop ini.

BA7m Bioskop ini mengingatkan saya akan kenangan indah di hidup saya.

BC1 Saya akan terus menjadi pelanggan bioskop ini.

BC2 Bila bioskop ini mengecewakan saya sekali dua kali, saya tidak terlalu mempersalahkannya.

BC3 Saya akan kecewa bila ingin menonton ternyata bioskop ini penuh.

BC4 Saya akan pindah ke bioskop lain apabila bioskop ini penuh(-).

BC5 Saya merasa puas setelah menonton di bioskop ini.

PWOM1 Saya akan menyarankan keluarga dan kenalan saya untuk menonton di sini.

PWOM2 Saya membagikan pengalaman pribadi saya ketika menonton bioskop di sini kepada teman-teman saya. PWOM3 Saya membicarakan hal yang positif mengenai bioskop ini kepada teman-teman saya.

PWOM4 Saya akan membicarakan hal-hal positif mengenai keunggulan bioskop ini dibandingkan bioskop di tempat lain

PWOM5 Saya akan merekomendasikan bioskop ini kepada teman-teman saya.
Metode analisis untuk menguji hipotesis 1, 2 dan 3 menggunakan regresi dengan variabel mediator atau intervening dan analisis jalur. Sehingga hasil penelitian ini dapat menjelaskan apakah brand love mempengaruhi positive WOM, baik secara langsung maupun melalui brand commitment. Untuk menguji pengaruh variabel intervening digunakan metode

\section{ANALISIS DAN PEMBAHASAN}

Sebelum dilakukan analisis untuk memecahkan masalah penelitian, dilakukan uji validitas dan reliabilitas setiap variabel. Hasil uji validitas dan reliabilitas menunjukkan data sudah memiliki tingkat validitas dan reliabilitas yang cukup baik. Hal ini setelah dilakukan penghapusan respon yang tidak konsisten sehingga didapat 153 respon yang dapat digunakan dalam analisis selanjutnya. Uji reliabilitas menggunakan Cronbach Alpha dan validitas menggunakan korelasi antar butir pertanyaan dengan skor total setiap variabel. Untuk Cronbach alpha berkisar $0,6-0,8$. Sedangkan untuk uji validitas menunjukkan semua butir pernyataan signifikan terhadap skor total masingmasing. analisis jalur. Analisis jalur merupakan perluasan dari analisis regresi linear berganda. Analisis jalur adalah penggunaan analisis regresi untuk menaksir hubungan kausalitas antar variabel yang telah ditetapkan sebelumnya berdasarkan teori. Signifikansi mediasi diuji dengan Sobel Test.

Analisis pengaruh variabel independen (Brand Love) terhadap variabel dependen (Positive WOM) secara langsung maupun melalui variabel mediasi (Brand Commitment) menggunakan analisis persamaan regresi analisis jalur (path analysis) dan Sobel Test untuk menguji hipotesis.

\section{Analisis Pengaruh Brand Love terhadap Positive Word of Mouth secara langsung dan melalui Variabel Mediator Brand Commitment.}

Untuk memecahkan rumusan masalah pertama yaitu mengetahui pengaruh variabel independen (Brand Love) terhadap variabel dependen (positive WOM) baik secara langsung maupun bila 
melalui variabel intervening/ mediasi (Brand Commitment) maka dilakukan dengan persamaan regresi di bawah ini.

Persamaan Regresi Pengaruh Brand Love terhadap Positive Word of Mouth dengan Variabel Mediator: Brand Commitment

$\mathrm{X}$ : Variabel Independen : Brand Love

Y : Variabel Dependen: Positive WOM

M: Variabel Mediator: Brand Commitment

$$
\begin{aligned}
& Y=\propto 1+c X \\
& M=\propto 2+a X \\
& Y=\propto 3+c^{\prime} X+b M
\end{aligned}
$$

Hasil ouput analisis untuk ketiga model tersebut dapat dilihat pada Tabel 2 s.d. 4 .

\section{Pengujian Hipotesis (H1, H2a, H2b, dan H3)}

Variabel $M$ disebut mediator atau intervening jika persamaan (1) $\mathrm{X}$ secara signifikan mempengaruhi $\mathrm{Y}$ (atau $\mathrm{c} \neq 0$ ), persamaan (2) $\mathrm{X}$ secara signifikan mempengaruhi $\mathrm{M}$ (atau $\mathrm{a} \neq 0$ ) dan persamaan (3) $M$ secara signifikan mempengaruhi $\mathrm{Y}$ dengan mengontrol $\mathrm{X}$ (atau $b \neq 0$ ).

Jika pengaruh $\mathrm{X}$ terhadap $\mathrm{Y}$ signifikan dan menurun menjadi nol dengan memasukkan variabel $\mathrm{M}$, maka terjadi mediasi sempurna (perfect mediation). Namun demikian, jika pengaruh $X$ terhadap $\mathrm{Y}$ signifikan dan menurun tidak sama dengan nol dengan memasukkan variabel $\mathrm{M}$, maka terjadi mediasi parsial (partial mediation). Mediasi sederhana ini terjadi jika dipenuhi asumsi : (1) tidak ada kesalahan pengukuran (measurement error) pada variabel $M$, dan (2) Variabel $Y$ tidak mempengaruhi M. (Ghozali, 2017:236).

Pengujian hipotesis mediasi dapat dilakukan dengan prosedur yang dikembangkan oleh Sobel (1982) dan dikenal dengan uji Sobel (Sobel test). Uji Sobel dilakukan dengan cara menguji kekuatan pengaruh tidak langsung $\mathrm{X}$ ke $\mathrm{Y}$ lewat M. Pengaruh tidak langsung $X$ ke $Y$ lewat $\mathrm{M}$ dihitung dengan cara mengalikan jalur $\mathrm{X} \rightarrow \mathrm{M}$ (a) dengan jalur $\mathrm{M} \rightarrow \mathrm{Y}$ (b) menjadi $a b$. Jadi koefisien $a b=(c-c ')$, di mana $\mathrm{c}$ adalah pengaruh $\mathrm{X}$ terhadap $\mathrm{Y}$ tanpa mengontrol $\mathrm{M}$, sedangkan c' adalah koefisien pengaruh $\mathrm{X}$ terhadap $\mathrm{Y}$ setelah mengontrol M. Standard error koefisien a dan $b$ ditulis dengan $s_{a}$ dan $s_{b}$ dan besarnya standard error pengaruh tidak langsung (indirect effect) adalah $\mathrm{s}_{\mathrm{ab}}$ yang dihitung dengan rumus di bawah ini:

$$
s a b=\sqrt{b^{2} s a^{2}+a^{2} s b^{2}+s a^{2} s b^{2}}
$$

Untuk menguji signifikansi pengaruh tidak langsung, perlu dihitung nilai $t$ dari koefisien $a b$ dengan rumus sebagai berikut:

$$
t=\frac{a b}{s a b}
$$

Nilai $\mathrm{t}$ hitung ini dibandingkan dengan nilai $\mathrm{t}$ tabel, jika nilai $\mathrm{t}$ hitung $>$ nilai $\mathrm{t}$ tabel maka dapat disimpulkan terjadi pengaruh mediasi. Asumsi uji Sobel

\begin{tabular}{|c|c|c|c|c|c|c|}
\hline \multicolumn{7}{|c|}{ Coefficients $^{\mathrm{a}}$} \\
\hline & & Unstandardize & oefficients & $\begin{array}{l}\text { Standardized } \\
\text { Coefficients }\end{array}$ & & \\
\hline \multicolumn{2}{|l|}{ Model } & B & Std. Error & Beta & $\mathrm{t}$ & Sig. \\
\hline \multirow[t]{2}{*}{1} & (Constant) & 5.400 & 486 & & 11.102 & .000 \\
\hline & Brand LOVE & 2.04 & .106 & .155 & 1.926 & .036 \\
\hline
\end{tabular}
memerlukan ukuran sampel yang besar karena bila sampe kecil maka uji Sobel menjadi kurang konservatif.

Tabel 2. Model 1, Persamaan $Y=\propto 1+c X$

Hasil output SPSS memberikan nilai beta Brand Love pada persamaan (1) sebesar 2,04 dan signifikan pada 0.036 yang berarti bahwa Brand Love mempengaruhi
$P W O M$ secara langsung. Sehingga dapat dikatakan bahwa hipotesis 3 diterima atau dengan kata lain Brand Love secara 
langsung berpengaruh positif terhadap Positive Word of Mouth (PWOM).

Tabel 3. Model 2, Persamaan $M=\propto 2+a X$

\begin{tabular}{|c|c|c|c|c|c|c|}
\hline \multicolumn{7}{|c|}{ Coefficients $^{\mathrm{a}}$} \\
\hline & & Unstandardizec & oefficients & $\begin{array}{l}\text { Standardized } \\
\text { Coefficients }\end{array}$ & & \\
\hline \multicolumn{2}{|c|}{ Model } & B & Std. Error & Beta & $\mathrm{t}$ & Sig. \\
\hline \multirow[t]{2}{*}{1} & (Constant) & 4.604 & .466 & & 9.879 & .000 \\
\hline & Brand LOVE & 2.20 & .101 & .216 & 1.942 & .047 \\
\hline
\end{tabular}

Berdasar pada persamaan 2, beta Brand Love terhadap Brand Commitment sebesar 2,20 dan signifikan pada 0,047. Sehingga dapat dikatakan hipotesis 2 a dapat diterima yaitu Brand Love berpengaruh positif terhadap Brand Commitment.

Tabel 4. Model 3, Persamaan $Y=\propto 3+c^{\prime} X+b M$

\begin{tabular}{|c|c|c|c|c|c|c|}
\hline \multicolumn{7}{|c|}{ Coefficients $^{\mathrm{a}}$} \\
\hline & & Unstandardized & efficients & $\begin{array}{l}\text { Standardized } \\
\text { Coefficients }\end{array}$ & & \\
\hline \multicolumn{2}{|l|}{ Model } & B & Std. Error & Beta & $\mathrm{t}$ & Sig. \\
\hline \multirow[t]{3}{*}{1} & (Constant) & 4.967 & .624 & & 7.965 & .000 \\
\hline & Brand LOVE & 2.02 & 106 & .153 & 1.910 & .058 \\
\hline & Brand Commit & .094 & .085 & .089 & 1.108 & .027 \\
\hline
\end{tabular}

Dari persamaan 3 di atas beta Brand Commitment terhadap PWOM sebesar 0,094 signifikan pada 0,027. Sehingga dapat dikatakan hipotesis $\mathbf{2 b}$ dapat diterima yaitu Brand Commitment berpengaruh positif terhadap Positive Word of Mouth (PWOM). Pengaruh X terhadap $\mathrm{Y}$ signifikan pada persamaan 1 $(b=2,04 ; p=0,036)$ dan menurun tidak sama dengan nol dengan memasukkan variabel $M$ pada persamaan $3(b=2,02$; $\mathrm{p}=0,58)$, maka terjadi mediasi parsial (partial mediation).

Untuk menguji hipotesis 1 dilakukan analisis jalur menggunakan persamaan 2 dan 3. Pada persamaan (2) beta sebesar 2,20 dan signifikan pada 0,047 yang berarti Brand Love mempengaruhi Brand Commitment. Beta 2,20 merupakan nilai path atau jalur p2. Pada output SPSS persamaan regresi (3) beta Brand Love sebesar 2,02 yang merupakan nilai jalur $\mathrm{p} 1$ (sig. 0,058) dan Brand Commitment sebesar 0,094 yang merupakan nilai jalur p3 (sig. 0,027). Besarnya nilai $\mathrm{e} 1=$ $\sqrt{(1-0,426}=0,757$ dan nilai e2 $=$ $\sqrt{(1-0,325}=0,821$.

Hasil analisis jalur menunjukkan bahwa Brand Love dapat berpengaruh secara langsung terhadap PWOM dan dapat juga berpengaruh secara tidak langsung yaitu melalui Brand Commitment. Besarnya pengaruh langsung adalah $(\mathrm{p} 2=2,02)$ sedangkan besarnya pengaruh tidak langsung adalah sebesar = p1 xp3 $=2,20 \times 0,094=0,2068$. Sehingga total pengaruh Brand Love terhadap $P W O M$, yang merupakan penjumlah jalur langsung dan tidak langsung sebesar = $2,02+0,2068=2,2268$.

\section{e 0,757}




\section{Gambar 2. Analisis Jalur Brand Love, Brand Commitment, dan PWOM}

Pengaruh mediasi yang ditunjukkan oleh perkalian koefisien ( p2xp3) sebesar $\mathbf{0 , 2 0 6 8}$ signifikan atau tidak, diuji dengan Sobel Test sebagai berikut:

$$
\begin{gathered}
S a b=\sqrt{b^{2} s a^{2}+a^{2} s b^{2}+s a^{2} s b^{2}} \\
S a b=\sqrt{(0,094)^{2}(0,101)^{2}+(2,20)^{2}(0,085)^{2}+(0,101)^{2}(0,085)^{2}} \\
S a b=\sqrt{0,000090136+0,034969+0,0000737}=\mathbf{0 , 0 3 5 1}
\end{gathered}
$$

Berdasar hasil standar error ( $S a b)$ di atas maka dihitung nilai t statistik pengaruh mediasi dengan rumus sbb.:

$$
\begin{gathered}
t=\frac{a b}{s a b} \\
t=\frac{2,2 \times 0,094}{0,0351} \\
=63,441
\end{gathered}
$$

Dari hasil perhitungan, nilai t hitung 63,441 lebih besar dari $\mathrm{t}$ tabel dengan tingkat signifikansi 0,05 yaitu sebesar 1,97, maka dapat disimpulkan bahwa koefisien mediasi 0,2068 signifikan yang berarti ada pengaruh mediasi. Dengan demikian hipotesis 1 dapat diterima.
Selain itu perlu juga memenuhi asumsi bahwa tidak ada hubungan timbal balik dari variabel dependen terhadap variabel mediator. Dari output di bawah ini terbukti

\begin{tabular}{|c|c|c|c|c|c|c|}
\hline \multicolumn{7}{|c|}{ Coefficients $^{\mathrm{a}}$} \\
\hline & & Unstandardize & efficients & $\begin{array}{l}\text { Standardized } \\
\text { Coefficients }\end{array}$ & & \\
\hline \multicolumn{2}{|l|}{ Model } & B & Std. Error & Beta & $\mathrm{t}$ & Sig. \\
\hline \multirow[t]{2}{*}{1} & (Constant) & 4.127 & .343 & & 12.031 & .000 \\
\hline & PWOM & .087 & .077 & .091 & 1.128 & .261 \\
\hline
\end{tabular}
bahwa PWOM (Y) tidak signifikan mempengaruhi Brand Commitment (M). Sehingga asumsi memenuhi syarat untuk mediasi sederhana ini.

Tabel 5. Uji pengaruh PWOM terhadap Brand Commitment (Y terhadap M) 


\begin{tabular}{|c|c|c|c|c|c|c|}
\hline \multicolumn{7}{|c|}{ Coefficients $^{\mathrm{a}}$} \\
\hline & & Unstandardizec & efficients & $\begin{array}{l}\text { Standardized } \\
\text { Coefficients }\end{array}$ & & \\
\hline \multicolumn{2}{|l|}{ Model } & $\mathrm{B}$ & Std. Error & Beta & $\mathrm{t}$ & Sig. \\
\hline \multirow[t]{2}{*}{1} & (Constant) & 4.127 & .343 & & 12.031 & .000 \\
\hline & PWOM & . 087 & .077 & .091 & 1.128 & .261 \\
\hline
\end{tabular}

\section{Karakteristik Responden}

Dari karakteristik responden terlihat bahwa 125 orang responden sebagai pelanggan bioskop menjadi pelanggan untuk lebih dari 1 bioskop. Hal ini memperlihatkan kesetiaan pada beberapa merek (bioskop) sekaligus. Terlihat pula bahwa sebagian besar memiliki kartu keanggotaan sebagai pelanggan yang menunjukkan program CRM yang dilaksanakan perusahaan. Kali menonton dan waktu menjadi pelanggan merupakan syarat minimal yang harus dipenuhi sebagai responden karena waktu hubungan dan intensitas hubungan menunjukkan adanya hubungan merek dengan konsumen yang cukup erat.

Tabel 6. Karakteristik Responden

\begin{tabular}{cllc}
\hline No. & \multicolumn{1}{c}{ Karakteristik } & \multicolumn{1}{c}{ Pilihan } & Jumlah \\
\hline 1. & Jenis Kelamin & Perempuan & 97 \\
& & Laki-laki & 56 \\
\hline 2. & Usia & a.17-22: & 58 \\
& & b. 23-28: & 35 \\
& & c. 29-34: & 34 \\
& & d. 35-40: & 17 \\
& & e. 41-46: & 7 \\
\hline 3. & Menonton di bioskop lain juga & f. >46: & 2 \\
\hline 4. & & Berapa kali menonton dalam waktu 6 bulan terakhir & 125 \\
& & Ya : & 28 \\
\hline 5. & Waktu menjadi pelanggan bioskop & a. 3-6 kali & 71 \\
& & b. 7-10 kali & 49 \\
& & c. Lebih dari 10 kali & 33 \\
\hline 6. & Memiliki kartu keanggotaan/ Member & a. 6-12 bulan & 117 \\
& & b. Lebih dari 1 tahun & 36 \\
\hline & & a. Ya & 127 \\
\hline
\end{tabular}

\section{KESIMPULAN DAN SARAN}

Hasil penelitian ini dapat disimpulkan sebagai berikut dengan tidak lupa mengingat beberapa keterbatasan dalam penelitian ini.

1. Brand Love atau kecintaan terhadap merek memiliki dampak terhadap Positive Word of Mouth melalui Brand Commitment atau komitmen terhadap merek sebagai variabel mediator (H1). Brand Commitment merupakan mediator atau perantara antara Brand Love dengan PWOM.

2. a) Brand Love berpengaruh positif terhadap Brand Commitment (H2a). b) Brand Commitment memiliki dampak positif terhadap $P W O M$ (H2b).

3. Brand love berpengaruh positif secara langsung terhadap PWOM (H3).

Untuk Nomor 1 s.d. 3 hal ini dapat dipahami bila konsumen yang sudah sampai taraf mencintai mereknya akan mempertahankan hubungan jangka panjang dan akan cenderung berbicara positif mengenai pilihan mereknya apalagi yang sudah jangka panjang dikonsumsi. Temuan ini cocok dengan Albert \& Merunka (2013), Tuskej, et.al., (2013), 
Bachman \& Wilkins (2014), Sallam, M.A. (2015), dan Sweiden, K.M. (2016).

\section{Keterbatasan dan Saran}

Penelitian ini dapat kembali dilaksanakan untuk jenis bisnis yang berbeda, yang dapat menghasilkan karakteristik yang berbeda dari hubungan konsumen dengan mereknya. Karena keterbatasan tenaga, waktu dan dana penelitian, sampel penelitian sebesar 153 responden masih dirasa kurang sehingga untuk penelitian yang memungkinkan sampel lebih besar lebih disarankan untuk mendapatkan hasil penelitian yang lebih signifikan/ konservatif. Selain itu dalam penelitian ini belum terungkap mengenai kondisi-kondisi yang memungkinkan konsumen untuk mencintai merek, berkomitmen serta menyebarkan WOM positif mengenai beberapa merek sekaligus. Sehingga untuk penelitian selanjutnya dapat dikembangkan ke arah itu. Di mana kesetiaan yang terjadi di antara konsumen dengan merek adalah kesetiaan pada lebih dari 1 merek. Sehingga mungkin program promosi penjualan yang ditawarkan perusahaan lain merupakan faktor penting untuk membuat pelanggan beralih atau mempertahankan komitmen pada beberapa merek..

\section{DAFTAR PUSTAKA}

Aaker, J. (1997), Dimension of brand personality. Journal of Marketing Research, 34(3), 347-356.

Agustinus, M. (2015), Bisnis Bioskop Dibuka Lebar untuk Asing, Ini Kritik Pengusaha Lokal, Detik Finance (10 Desember 2015).

Akin, M. (2017), The Effect of Young Consumers' Love for Smart Mobile Phone Brands on Brand Loyalty. International Review of Management and Business Research, 6(1), 362370. ISSN: 2306-9007.

Albert, N., \& Merunka, D. (2013). The role of brand love in consumer-brand relationships. Journal of Consumer Marketing, 30(3), 258-266. Doi:10.1108/0736761311328928.

Albert, N., Merunka, D., Valette-Florence, P. (2008), When consumers love their brands: Exploring the concept and its dimensions. Journal of Business Research, 61(10), 10621075.

Bachman, K., \& Wilkin, S. (2014). Brand Commitment and consumer-brand identification as determinants of consumers' brand loyalty and repurchase intentions. Research with Plymouth University, 11-32.

Batra, R., Ahuvia, A.C., Bagozzi, R.(2012), Brand Love. Journal of Marketing, 76(2), 1-16.

Bauer, H., Heinrich, D., Albrecht, C. (2009)"All You Need is Love: Assessing Consumers' Brand Love" American Marketing Association Summer Educator Conference, Agustus 7-10, Chicago.

Carroll, B.A, Ahuvia, A.C. (2006), Some antecedents and outcomes of brand love. Marketing Letters, 17(2), 79-89.

Fournier, S.(1998), Consumers and their brands: developing relationship theory in consumer research. Journal of Consumer Research, 24(4), 343-353.

Ghani, NHBA., and Tuhin, MKW. (2016), Consumer Brand Relationships. International Review of Management and Marketing, 6(4), 950-957.

Ghozali, Imam (2017), Aplikasi Analisis Multivariate dengan Program IBM SPSS 23, Semarang: Badan Penerbit Universitas Diponegoro, Edisi 8. ISBN: 979.704.015.1. 
Gupta, Richa (2017), Collision Between Customer Inertial Factor and Brand Love: Tranformations in Re-purchase Intentions, International Journal of Engineering Research and Application, Vol.7, Issue 9, Part-1, 27-38. ISSN:2248-9622, www.ijera.com.

Hair, J.F., Black, W.C., Babin, B.J., Anderson, R.E., Tatham, R.L. (2006), Multivariate Data Analysis, 6. Baski, New Jersey, Prentice Hall.

Hassan,M., Rafi, A., Kazmi, SS., (2016), Impact of Differentiated Customer Service, Brand Trust, Brand Commitment, and Brand Salience on Brand Advocacy, International Review of Management and Marketing, 6(S4)232-238.

Hutfield, E., Rapson, RL. (1993), Love, Sex, and Intimacy: Their Psychology, Biology, and History. New York: Harper Collins College Publishers.

Keller, K.L. (2001), Building Customer-Based Brand Equity: A Blueprint for Creating Strong Brands. Boston, M.A: Marketing Science Institute.

Kumar , R. (2006), Marketing and Branding: The Indian Scenario. New Delhi: Pearson Education India.

Kusumawardhani, A. (2017), Bisnis Bioskop: Ekspansi Daerah Bergantung Kesuksesan Film Nasional, Bisnis Indonesia (10 Juli 2017).

Levy, Michael and Weitz, Barton A. (2014), Retailing Management, New York: Mc GrawHill Education, 9th Ed.

Maisam, S., and Mahsa, R-d. (2016), Positive Word of Mouth Marketing: Explaining the Roles of Value Congruity and Brand Love. Journal of Competitiveness, 8(1), 19-37. ISSN 1804-171X (print), ISSN 1804-1728 (On-line), DOI:10.7441/joc.2016.01.02.

Mehta, Subhash C., Lalwani, Ashok K., dan Han, Soon-Li (2000). Measuring the Service Quality of Retailers Distributing Technical Products with High Service Component: An Evaluation and Extension. Journal of Proffesional Service Marketing, 20, 33-49. Publish online 24 Oktober 2008. https://doi.org/10.1300/J090v20n02_04.

Motahari, N.F., Amadi, S., Tolabi, Z., \& Allah pour, A.Y. (2014). Investigation of brandconsumer relationship: Atudy ite: Electrical appliances. Market management magazine, 23, 24-38.

Ogba, Ike-Elechi dan Tan, Zhenzhen (2009). Exploring the impact of brand image on customer loyalty and commitment in China. Journal of Technology Management in China. 4(2).pp.132-144. ISSN 1746-8779.

Rizwan, M., Jave, A., Aslam, J., Khan, R. (2014), The Relationship of Brand Commitment, Brand Credibility, Perceived Quality, Customer Satisfaction and Brand Loyalty: an Empirical Study on Stylo Shoes, Journal of Sociological Research, Vol.5No.1, ISSN:1948-5468. Doi:10.5296/jsr.v5i1.6572, URL: http://dx.doi.org/10.5296/jsr.v5i1.6572

Sallam, M.A.(2015), The Effect of Dual Image (Corporate and Brand) on Customers' WOM: The Role of Customer Loyalty, International Journal of Economics, Commerce and Management, Vol.III, Issue 12, December 2015, ISSN:23480386, http://ijeem.co.uk/

Sari, N.I. (2014), Mengintip Manisnya Bisnis Bioskop, Merdeka.com ( 9 Januari 2014).

Sekaran, Uma and Bougie, Roger (2017), Metode Penelitian untuk Bisnis, Jakarta : Salemba Empat, Buku 1\&2. ISBN : 978-979-061-744-5. 
Shimp, T.A., Madden, T.J. (1988), Consumer-object relations: A conceptual framework based analogously on Sternberg's triangular theory of love. Advances in Consumer Research, 15(1), 163-168.

Sichtmann, C. (2007). An analysis of antecedents and consequences of trust in corporate brand. European Journal of Marketing, 41(9/10), 999-1015. Doi: $10.1108 / 03090560710773318$.

Simpson, J.A., Fletcher, G.J.O., Lorne, C. (2001), The structure and function of ideal standards in close relationships. In: Fletcher, G.J.O., Clark, M.S., editors. Blackwell Handbook of Social Psychology. Vol.II. Interpersonal Processes. Malden, MA: Blackwell Publishing. P.86-106.

Stenberg, R.J. (1986), A triangular theory of love. Psychological Review, 93, 119-135.

Sweiden, KM., (2016), Factors Affecting the World of Mouth on Telecommunication Service Providers in Amman, A thesis submitted in partial fullfilment of Requirements fot the Master Degree in Business Administration Department of Business Administration, Faculty of Business, Middle East University.

Tuskej, U., Golob, U., \& Podnar, K. (2013). The role of consumer-brand identification in building brand relationship. Journal of Business Research, 66(1), 53-59, doi: 10.1016/jjbusres.2011.07.022.

Unal, S., Aydin, H.(2013). An investigation on the evaluation of the factors affecting brand love. Procedia-Social and Behavioral Sciences, 92, 76-85, doi:10.1016/j.sbspro.2013.08.640.

Wien, AH. (2015), Antecedents and Consequences of word of mouth, Consumer evaluation context individualism, personality and defense of companies, A dissertation for the degree of Philosophiae Doctor, Faculty of Biosciences, Fisheries and Economics, Troms $\emptyset$ University Business School.

Wirawan, J. (2017), Kebangkitan Bioskop Independen di Indonesia, BBC Indonesia (3 April 2017).

Ziaullah, M., Feng, Y., Akhter, S.N., \& Ahmad, S. (2015). An Investigation of Justice in Supply Chain Trust and Relationship Commitment - An Empirical Study of Pakistan. Journal of Competitiveness, 7(1), 71-87. Doi:10.7441/joc.2015.01.05 